Vol 25 No 2 Tahun 2020

\title{
EVALUASI KINERJA FASILITAS ASET KOMPLEK PERGUDANGAN PT. BHANDA GHARA REKSA (PERSERO) INDRAMAYU
}

\author{
Annisa Ayu Paramitha \\ Program Studi Manajemen Aset, Politeknik Negeri Bandung \\ Corresponding Author Email : annisa.ayu.mas16@polban.ac.id
}

\begin{abstract}
BGR warehousing area in Indramayu has a land area of 10,000 $\mathrm{m} 2$ with a warehouse area of 1,440 $\mathrm{m} 2$. Some indications of problems arising include leakage of gutters, shed of the warehouse floor, loss of shed iron doors, unclear parking areas, and the malfunction of some supporting facilities such as generator sheds and public toilets. The grand theory used in this research is the Key Performance Indicators (KPIs) of Warehouse Facilities. The method used in this research is descriptive research method using qualitative approaches and quantitative approaches. The results of this study are a measure of the performance of facilities in the Indramayu BGR warehousing area.
\end{abstract}

Keywords: Assets, Performance, KPI, Warehouse

\begin{abstract}
Abstrak
Komplek pergudangan BGR Indramayu memiliki luas lahan sebesar $10.000 \mathrm{~m} 2$ dengan luas bangunan gudang sebesar $1.440 \mathrm{~m} 2$. Timbul beberapa indikasi masalah yaitu kebocoran talang air, lantai gudang retak, pengeroposan pintu besi gudang, area parkir kurang jelas, dan tidak berfungsinya beberapa fasilitas penunjang yang seperti gudang genset dan toilet umum. Tujuan dari penelitian ini adalah untuk mengukur kinerja fasilitas di komplek pergudangan BGR Indramayu. Grand theory yang digunakan dalam penelitian ini yaitu Key Performance Indicators (KPIs) Fasilitas Gudang. Metode yang digunakan dalam penelitian ini adalah metode penelitian deskriptif dengan menggunakan pendekatan kualitatif dan pendekatan kuantitatif. Kondisi fisik dan fungsional bangunan buruk dilihat dari usia bangunan yang sudah tua dan fasilitas penunjang yang kurang memadai. Sehingga hasil dari penelitian ini menunjukan bahwa kinerja fasilitas di komplek pergudangan BGR Indramayu tidak optimal.
\end{abstract}

Kata Kunci : manajemen aset, kinerja, kpi, gudang, evaluasi 


\section{PENDAHULUAN}

PT. Bhanda Ghara Reksa (Persero) atau BGR Logistics merupakan salah satu Badan Usaha Milik Negara (BUMN) yang bergerak di bidang pergudangan dan jasa logistik. Bisnis utama BGR Logistics adalah menyediakan, menyewakan dan mengelola ruangan gudang, baik tertutup maupun terbuka (open storage) dan menyelenggarakan jasa pergudangan lainnya. Gagasan didirikannya BGR Logistics berdasarkan adanya kebutuhan badan usaha yang dapat mengelola fasilitas pendukung sarana distribusi pupuk yang memadai berupa fasilitas gudang yang lokasinya menjangkau ke sentra-sentra pertanian. Dalam perkembangannya, BGR Logistics menambah jasa-jasa trasportasi baik darat maupun udara dan pengurusan eskpor-impor serta mengkombinasikannya dengan jasa pergudangan yang telah ada menjadi paket-paket jasa logistik. Sejalan dengan itu, BGR Logistics melengkapi kegiatannya dengan jasa-jasa penunjang yang relevan yaitu jasa-jasa pest control dan fumigasi.

PT. Bhanda Ghara Reksa (Persero) Divre VII Bandung atau PT. BGR Bandung merupakan salah satu kantor cabang BGR Logistics yang bertanggung jawab untuk mengelola kegiatan pergudangan dan logistik di wilayah Jawa Barat. Aset tetap yang dikelola oleh PT. BGR Bandung berupa gudang dan armada pengangkut barang. Jumlah gudang yang dikelola PT. BGR Bandung sebanyak 24 gudang yang terdiri dari dua jenis gudang, yaitu gudang milik dan gudang sewa. Gudang milik merupakan gudang yang dimiliki dan dikelola langsung oleh PT. BGR, sedangkan gudang sewa merupakan gudang yang disewa dari pihak pertama oleh PT. BGR untuk dikelola dan disewakan kembali kepada pihak ketiga.

Gudang milik yang dikelola oleh PT. BGR Bandung di wilayah Jawa Barat terdiri dari 6 unit gudang. Sesuai dengan gagasan didirikannya BGR Logistics, gudang-gudang yang dibangun berlokasi di daerah yang dapat menjangkau ke sentra-sentra pertanian. Salah satunya berlokasi di Widasari, Indramayu. Komplek pergudangan BGR Indramayu ini terletak di tengah-tengah area persawahan, dan sudah beroperasi selama 44 tahun semenjak didirikan bersamaan dengan pendirian perusahaan yaitu pada tahun 1976. Berdasarkan umur aktualnya, komplek pergudangan BGR Indramayu telah melebihi umur ekonomis atau manfaat bangunan gudang yaitu 30 tahun (MAPPI, 2016). Sehingga bangunan gudang tersebut saat ini sudah melewati umur ekonomisnya selama 14 tahun.

Komplek pergudangan BGR Indramayu memiliki luas lahan sebesar $10.000 \mathrm{~m}^{2}$, dengan luas bangunan gudang sebesar $1.440 \mathrm{~m}^{2}$. Terdapat pula lahan seluas $4.070 \mathrm{~m}^{2}$ yang saat ini 
belum dipergunakan untuk kegiatan operasional sehingga dimanfaatkan sebagai lahan pertanian oleh warga sekitar. Fasilitas di komplek pergudangan ini terdiri dari gudang penyimpanan, kantor administrasi, pos jaga, 2 (dua) buah gudang genset, wc umum dan tempat parkir.

Menurut Mangano dkk (2014), kinerja fasilitas pada kawasan pergudangan dapat diukur berdasarkan Key Performance Indicators (KPIs). Adapun KPI yang perlu diperhatikan mencakup indikator: financial, physical, functional, dan survey-based (Lavy dkk, 2010). Namun, berdasarkan indikasi masalah yang timbul pada komplek pergudangan BGR Indramayu, penelitian ini dibatasi pada dua indikator utama yakni indikator physical dan indikator functional.

Di lihat dari segi fisiknya, terdapat beberapa indikasi masalah pada fasilitas di komplek pergudangan BGR Indramayu. Salah satunya terkait pemeliharaan aset. Pemeliharaan yang dilakukan di komplek pergudangan BGR Indramayu terbatas pada perawatan dari segi kebersihan dan perbaikan jika terjadi komponen yang mengalami kerusakan. Dari segi fungsinya, beberapa indikasi masalah yang terjadi yaitu kendaraan parkir disembarang tempat dan terdapat beberapa fasilitas yang tidak dapat digunakan. Maka perlu dilakukan studi kasus untuk mengetahui lebih mendalam terhadap indikasi masalah yang terdapat pada objek tersebut. Berdasarkan pemaparan indikasi permasalahan tersebut, dilakukan evaluasi kinerja aset fasilitas Komplek Pergudangan BGR Indramayu.

\section{TINJAUAN PUSTAKA}

\section{1) Manajemen Aset}

Setiap organisasi baik itu organisasi swasta maupun instansi pemerintah pasti memeliki aset yang harus di kelola. Aset dalam bahasa Indonesia dikenal dengan istilah kekayaan. Aset adalah segala sesuatu yang memiliki nilai ekonomi yang dapat dimiliki baik oleh individu, perusahaan maupun dimiliki pemerintah yang dapat dinilai secara finansial (Sugiama, 2013). Bidang ilmu yang mempelajari tentang pengelolaan aset yakni manajemen aset. Menurut Sugiama (2013:15), "Manajemen aset adalah ilmu dan seni untuk memandu pengelolaan kekayaan yang mencakup proses merencanakan kebutuhan aset, mendapatkan, menginventarisasi, melakukan legal audit, menilai, mengoperasikan, memelihara, membaharukan atau menghapuskan hingga mengalihkan aset secara efektif dan efisien”. Menurut (Asset Management Council of Australia dalam Hasting,2010) siklus manajemen aset fisik bertujuan untuk mencapai hasil yang diharapkan oleh suatu perusahaan. Dari definisi di atas dapat disimpulkan bahwa manajemen aset adalah suatu 
bidang keilmuan yang bertujuan untuk pengelolaan aset yang efektif dan efisien untuk mencapai tujuan sebuah organisasi. Tujuan manajemen aset menurut pendapat Siregar (2004: 198) yaitu efesiensi pemanfaatan dan pemilikan, terjaga nilai ekonomis dan objektivitas dalam pengawasan dan pengendalian peruntukan, penggunaan serta alih penguasaan.

Menurut Sugiama (2013) seluruh proses manajemen aset dapat juga disebut fungsi dalam manajemen aset/alur manajemen aset. Terdapat tahapan-tahapan dalam manajemen aset yang merupakan sub-unit kegiatan yang sistematis dan teritegrasi. Masing-masing tahapan saling mempengaruhi dan dipengaruhi. Seluruh kegiatan harus dilaksanakan dengan sebaik mungkin agar tidak terjadi kesalahan fatal. Secara umum alur dari manajemen aset adalah perencanaan aset, pengadaan aset, inventarisasi aset, legal audit aset, operasi aset, pemeliharaan aset, hingga pengalihan aset dan penghapusan aset.

\section{2) Key Performance Indicators (KPI) Fasilitas}

Key Performance Indicators atau KPI memberitahu apa yang harus dilakukan untuk meningkatkan kinerja secara dramatis. Menurut David (2014), KPI merupakan seperangkat ukuran yang focus terhadap aspek kinerja organisasi yang paling kritis bagi kesuksesan organisasi saat ini maupun di masa mendatang. Sedangkan Mitchell (2006) mengungkapkan KPI adalah metrics yang dipilih untuk menunjukkan kinerja dari beberapa sasaran strategis inti, dan untuk memonitor unsur-unsur penting dari sebuah program Optimalisasi Aset. KPI dipergunakan secara luas oleh para pemuka industri untuk menunjukkan kemajuan pencapaian sasaran dan memperkuat ownership serta motivasi. KPI diperbaharui dan di sebarluaskan secara teratur, sehingga seluruh sasaran yang ingin dicapai diketahui oleh semua pihak yang terlibat. KPI juga dipergunakan untuk mengukur pencapaian jangka pendek.

Lavy dkk (2010) mengusulkan daftar KPI diklasifikasikan di bawah kategori berikut: keuangan, fisik, fungsional, dan survei berbasis. Mereka menyatakan bahwa pendekatan manajemen fasilitas (MF) yang kuat dapat mendukung misi organisasi, realisasi kebutuhan fasilitas di masa depan, biaya lebih efisien, dan mampu mengantisipasi hasil dari keputusan manajemen saat ini. Sebaliknya, MF yang buruk dapat mengakibatkan fasilitas yang tidak memadai untuk mendukung fungsi, tidak memberikan kontribusi untuk misi organisasi, tidak efisiennya biaya, dan tidak tersedianya fasilitas untuk kebutuhan di masa depan.

\section{a. Indikator Biaya}


Semua indikator terkait biaya dikelompokkan dalam kategori indikator keuangan yang menyatakan biaya dan pengeluaran fasilitas, bangunan, serta sistem dan komponennya. Indikator keuangan ini berbeda dari KPI dalam kategori lain karena memberikan penilaian cepat atas kinerja keuangan dan dapat digunakan untuk pengambilan keputusan jangka pendek maupun jangka panjang oleh berbagai tingkat manajemen di fasilitas tersebut. KPI keuangan ini mewakili kinerja dalam hal mata uang yang dikeluarkan per satuan luas, orang, atau keluaran / produk. Indikator yang disebutkan di atas memberikan penilaian keuangan holistik atas kinerja fasilitas Indikator seperti biaya hunian, biaya operasi, dan biaya pemeliharaan tanah. Memberikan perkiraan biaya saat ini di fasilitas atau organisasi, sementara indikator seperti pemeliharaan yang ditangguhkan dan pembaruan modal menyatakan biaya yang akan datang yang saat ini ditangguhkan. Biaya modal dan CRV menunjukkan pengeluaran besar berkala yang diperlukan untuk perluasan properti, pabrik, dan peralatan untuk pengembangan organisasi.

\section{b. Indikator Fisik}

Kondisi fisik bangunan atau fasilitas yang diteliti diklasifikasikan ke dalam kategori indikator fisik. Kategori ini merupakan keadaan fisik bangunan dalam hal kesesuaian (seberapa baik bangunan mendukung fungsi yang diinginkan), kualitas ruang (spatial, lingkungan, dan masalah psikologis), aksesibilitas (situs, lokasi, dan cacat aksesibilitas), dan sumber daya konsumsi (energi, air, dan material). Kategori ini mengandung indikator kualitatif maupun kuantitatif. KPI yang disebutkan di atas mencakup aspek luas dari kondisi fisik suatu bangunan karena menggabungkan indikator yang menunjukkan kualitas ruang serta aspek spasial dan volumetrik dari suatu ruang. Selanjutnya, keadaan kondisi fisik fasilitas yang dinyatakan oleh indikator kuantitatif (mis. BPI) dan kualitatif (mis. Kondisi fisik Bangunan) terkait dengan konsumsi sumber daya. Misalnya, fasilitas dengan kondisi fisik yang buruk, seperti sistem HVAC yang buruk, dapat menghasilkan konsumsi energi yang relatif lebih tinggi. Studi yang bertujuan pada penilaian fisik bangunan atau fasilitas dapat memanfaatkan KPI ini untuk pengukuran kinerja yang relevan.

\section{c. Indikator Fungsional}

Indikator fungsional digunakan dalam mengukur kinerja fungsi bangunan atau fasilitas dengan mengevaluasi aspek yang berkaitan dengan misi organisasi atau bisnis, ruang, karyawan, dan fasilitas pendukung lainnya. Ruang yang digunakan secara berlebihan dan yang kurang dimanfaatkan dapat mengungkapkan keadaan pemanfaatan ruang dalam suatu bangunan, sementara tingkat produktivitas dan turnover dapat menentukan kepuasan 
penghuni dengan bangunan atau fasilitas tersebut. Daftar KPI dalam kategori ini menjelaskan aspek-aspek seperti kecukupan ruang dan fasilitas pendukung, produktivitas penghuni bangunan, serta mengekspresikan seberapa baik aspek ini berkontribusi untuk mencapai bisnis jangka panjang atau tujuan organisasi. Indikator-indikator ini dapat dimanfaatkan untuk menetapkan tujuan jangka panjang dan untuk perencanaan strategis oleh manajemen senior.

\section{d. Indikator Berbasis Survei}

KPI yang tidak dapat diukur atau didapatkan dengan mengkomunikasikan pendapat responden dikelompokkan dalam kategori indikator berbasis survei. Survei biasanya menggunakan kuesioner di mana pertanyaan tergantung pada jenis penelitian yang dilakukan. Responden dapat mencakup penghuni bangunan, seperti karyawan penuh dan paruh waktu, atau penghuni sementara, seperti pelanggan atau pengunjung, dan / atau responden lainnya, seperti yang dipersyaratkan oleh penelitian. Indikator ini dapat berguna untuk para profesional dalam mengukur aspek lingkungan dan psikologis dari bangunan atau fasilitas, dimana informasi yang paling penting didapatkan dari reaksi dan pendapat responden. Hasil studi berbasis survei ini sangat tergantung pada jumlah tanggapan dan karakteristik demografi dari para responden (usia, jenis kelamin, lokasi).

\section{3) Gudang}

Gudang adalah lokasi untuk penyimpanan produk sampai permintaan (demand) cukup besar untuk melaksanakan distribusinya (Bowersox, 1978:293). Penyimpanan dianggap perlu untuk menyesuaikan produk dengan kebutuhan konsumen. Prinsip kegunaan waktu (time utility) dijadikan alas an untuk membenarkan alas an ini. Untuk manufaktur yang memproduksi berbagai produk di banyak lokasi, pergudangan memberikan metode untuk mengurangi biaya penyimpanan bahan mentah, dan suku cadang serta biaya penanganan, di samping memaksimumkan operasi produksi. Persediaan dasar untuk seluruh suku cadang dapat dipertahankan di gudang sehingga dapat menurunkan kebutuhan penumpukan persediaan di masing-masing pabrik. Pengertian lain tentang gudang adalah tempat yang dibebani tugas untuk menyimpan barang yang akan dipergunakan dalam produksi, sampai barang tersebut diminta sesuai jadwal produksi (Apple, 1990:242). 
Gudang dapat digambarkan sebagai suatu sistem logistik dari sebuah perusahaan yang berfungsi untuk menyimpan produk dan perlengkapan produksi lainnya dan menyediakan informasi mengenai status serta kondisi material/produk yang disimpan di gudang sehingga informasi tersebut mudah diakses oleh siapapun yang berkepentingan. Menurut Peraturan Menteri Perdagangan no. 90 tahun 2014 tentang Penataan dan Pembinaan Gudang, gudang adalah suatu ruangan tidak bergerak yang tertutup dan/atau terbuka dengan tujuan tidak dikunjung oleh umum, tetapi untuk dipakai khusus sebagai tempat penyimpanan barang. Tujuan dari adanya tempat penyimpanan dan fungsi dari pergudangan secara umum adalah memaksimalkan penggunaan sumber-sumber yang ada disamping memaksimalkan pelayanan terhadap pelanggan dengan sumber yang terbatas. Sumber daya gudang dan pergudangan adalah ruangan, Peralatan dan personil. Pelanggan membutuhkan gudang dan fungsi pergudangan untukm dapat memperoleh barang yang diinginkan secara cepat dan dalam kondisi yang baik.

Menurut Peraturan Kepala Badan Pengawas Perdagangan Berjangka Komoditi No. 3 Tahun 2007 tentang Persyaratan Umum Dan Persyaratan Teknis Gudang Tertutup Dalam Sistem Resi Gudang, klasifikasi Gudang komoditi pertanian berdasarkan pemenuhan persyaratan umum dan teknis dikelompokkan menjadi 3 (tiga), yaitu Gudang A, B, dan C. Gudang A merupakan gudang kualitas terbaik dengan fasilitas dan peralatan lengkap, gudang B merupakan gudang kualitas 2 dan gudang $\mathrm{C}$ merupakan gudang kualitas 3 . Klasifikasi gudang selengkapnya terdapat pada tabel 1 .

Tabel 1. Persyaratan Umum dan Persyaratan Teknis Gudang Berdasarkan Klasifikasi

\section{Gudang}

\begin{tabular}{|c|c|c|c|c|}
\hline \multirow{2}{*}{ No. } & \multirow{2}{*}{ Persyaratan } & \multicolumn{3}{|c|}{ Klasifikasi gudang } \\
\hline & & A & $\mathrm{B}$ & $\mathrm{C}$ \\
\hline \multicolumn{5}{|c|}{ I. Persyaratan Umum } \\
\hline \multicolumn{2}{|c|}{ Akses Transportasi } & $\begin{array}{l}\text { Jalan kelas I/ II/ } \\
\text { perairan }\end{array}$ & $\begin{array}{l}\text { Jalan kelas I/ II/ } \\
\text { perairan }\end{array}$ & $\begin{array}{l}\text { Jalan kelas I/ II/ } \\
\text { IIIA/ IIIB/ IIIC/ } \\
\text { perairan }\end{array}$ \\
\hline \multicolumn{5}{|c|}{ I. Persyaratan Teknis } \\
\hline \multicolumn{5}{|c|}{ A. Konstruksi Bangunan } \\
\hline 1 & Kerangka gudang & Besi baja & Besi baja & Kayu Keras \\
\hline 2 & $\begin{array}{l}\text { Atap gudang yang dapat } \\
\text { dilengkapi atap } \\
\text { pencahayaan }\end{array}$ & $\begin{array}{l}\text { Baja lembaran } \\
\text { lapis seng/ baja } \\
\text { lembaran lapis } \\
\text { alumunium }\end{array}$ & $\begin{array}{l}\text { Baja lembaran } \\
\text { lapis seng/ baja } \\
\text { lembaran lapis } \\
\text { alumunium }\end{array}$ & $\begin{array}{l}\text { Baja lembaran lapis } \\
\text { seng }\end{array}$ \\
\hline 3 & $\begin{array}{l}\text { Dinding gudang } \\
\text { a. Bahan dinding }\end{array}$ & - tembok & - tembok & - tembok terplester \\
\hline
\end{tabular}


Vol 25 No 2 Tahun 2020

\begin{tabular}{|c|c|c|c|c|}
\hline \multirow{2}{*}{ No. } & \multirow{2}{*}{ Persyaratan } & \multicolumn{3}{|c|}{ Klasifikasi gudang } \\
\hline & & \multirow{6}{*}{\begin{tabular}{l}
\multicolumn{1}{c}{ A } \\
terplester atau \\
- tembok \\
terplester dan \\
terlapis seng \\
minimal $6,00 \mathrm{~m}$
\end{tabular}} & B & \multirow{2}{*}{$\begin{array}{c}\mathrm{C} \\
\mathrm{dan} / \mathrm{atau}\end{array}$} \\
\hline & & & terplester atau & \\
\hline & b. Tinggi dinding & & - tembok & - minimal 4,00 m \\
\hline & & & terplester dan & \\
\hline & & & seng minimal & \\
\hline & & & 6,00 & \\
\hline \multirow[t]{5}{*}{4} & Lantai gudang & & & \\
\hline & a. Bahan lantai & Cor beton & Cor beton & Cor beton \\
\hline & b. Daya beban lantai & $>3,00$ ton $/ \mathrm{m}^{2}$ & $2,50-3,00$ ton $/ \mathrm{m}^{2}$ & $<2,50$ ton $/ \mathrm{m}^{2}$ \\
\hline & c. tinggi lantai dan tanah & & minimal $0,30 \mathrm{~m}$ & \\
\hline & & minimal $0,50 \mathrm{~m}$ & & minimal $0,30 \mathrm{~m}$ \\
\hline \multirow[t]{3}{*}{5} & Talang air & Baja lembaran & Baja lembaran & Baja lembaran lapis \\
\hline & & lapis seng/ pipa & lapis seng/ pipa & seng/ pipa PVC \\
\hline & & PVC & PVC & \\
\hline \multirow[t]{6}{*}{6} & Pintu gudang & & & \\
\hline & a. Bahan pintu & Plat besi/kayu & Plat besi/kayu & Plat besi/kayu \\
\hline & b. Lebar pintu & Minimal 4,00 m & Minimal 4,00 m & Minimal 3,00 m \\
\hline & c. Tinggi pintu & Minimal 3,50 m & Minimal 2,25 m & Minimal 2,25 m \\
\hline & d. Jumlah pintu & Minimal 2 pintu & Minimal 2 pintu & Minimal 1 pintu \\
\hline & e. Panjang kanopi & Minimal 4,00 m & Minimal 4,00 m & Minimal 3,00 m \\
\hline \multirow[t]{3}{*}{7} & Jarak Ventilasi dari & & & \\
\hline & a. Atap & $0,75-1,25 \mathrm{~m}$ & $0,75-1,25 \mathrm{~m}$ & $0,30-0,50 \mathrm{~m}$ \\
\hline & b. Lantai & $0,50 \mathrm{~m}$ & $0,50 \mathrm{~m}$ & $0,50 \mathrm{~m}$ \\
\hline 8 & Lebar teritis & $0,90-1,10 \mathrm{~m}$ & $0,90-1,10 \mathrm{~m}$ & $0,90-1,10 \mathrm{~m}$ \\
\hline \multicolumn{5}{|c|}{ B. Fasilitas Gudang } \\
\hline \multirow[t]{6}{*}{1} & Identitas pengaturan & & & \\
\hline & Lorong & & & \\
\hline & a. Lorong pokok & Minimal 1,50 m & Minimal $1,50 \mathrm{~m}$ & Minimal $1,00 \mathrm{~m}$ \\
\hline & b. Lorong silang & Minimal $1,00 \mathrm{~m}$ & Minimal $0,75 \mathrm{~m}$ & - \\
\hline & c. Lorong stampel & Minimal $0,50 \mathrm{~m}$ & Minimal $0,50 \mathrm{~m}$ & - \\
\hline & d. Lorong kebakaran & Minimal $0,75 \mathrm{~m}$ & Minimal $0,75 \mathrm{~m}$ & Minimal $0,50 \mathrm{~m}$ \\
\hline \multirow[t]{6}{*}{2} & a. Instalasi air & Ada & Ada & Ada \\
\hline & b. Instalasi listrik & Ada & Ada & Ada \\
\hline & c. Instalasi telepon & Ada & Ada & Ada \\
\hline & d. Instalasi hydrant & Ada & Ada & - \\
\hline & e. Generator & Ada & - & - \\
\hline & f. Penangkal petir & Ada & Ada & - \\
\hline 3 & Saluran air & Ada & Ada & Ada \\
\hline 4 & $\begin{array}{l}\text { Letak kantor atau ruang } \\
\text { administrasi }\end{array}$ & Di luar gudang & Di luar gudang & Di luar gudang \\
\hline \multirow[t]{4}{*}{5} & Sistem keamanan & & & \\
\hline & a. Ruang jaga & Di luar gedung & Di luar gedung & Di luar gedung \\
\hline & b. Alarm/tanda bahaya & Ada & Ada & Ada \\
\hline & c. Pagar & Ada & Ada & Ada \\
\hline
\end{tabular}




\begin{tabular}{lllll}
\hline \multirow{2}{*}{ No. } & \multirow{2}{*}{ Persyaratan } & \multicolumn{3}{c}{ Klasifikasi gudang } \\
\cline { 3 - 5 } & & \multicolumn{1}{c}{ B } & \multicolumn{1}{c}{ C } \\
\hline 6 & Kamar mandi/WC & Di luar gedung & Di luar gedung & Di luar gedung \\
\hline 7 & Luas area parkir & Minimal $500 \mathrm{~m}^{2}$ & Minimal $350 \mathrm{~m}^{2}$ & Minimal $200 \mathrm{~m}^{2}$ \\
\hline 8 & $\begin{array}{l}\text { Fasilitas sandar dan } \\
\text { bongkar muat }\end{array}$ & Ada & Ada & Ada \\
\hline $\begin{array}{llll}\text { C. } \text { Peralatan Gudang } \\
1\end{array}$ & Alat timbang bertera sah & Ada & Ada & Ada \\
\hline 2 & Palet kayu/plastik & Ada & Ada & Ada \\
\hline 3 & Alat Ukur & Ada & Ada & Ada \\
\hline & $\begin{array}{l}\text { a. } \text { Higrometer } \\
\text { b. } \text { Termometer }\end{array}$ & Ada & Ada & Ada \\
\hline 4 & Tangga staple & Ada & Ada & Ada \\
\hline 5 & $\begin{array}{l}\text { Alat pemadam } \\
\text { kebakaran }\end{array}$ & Ada & Ada & Ada \\
\hline 6 & Kotak P3K dan obat & Ada & Ada & Ada \\
\hline 7 & Alat kebersihan & Ada & Ada & Ada \\
\hline
\end{tabular}

\section{METODE PENELITIAN}

Berdasarkan perhitungan diatas, dapat diketahui bahwa fasilitas gudang penyimpanan, kantor administrasi, dan pos jaga digunakan secara optimal. Sedangkan kedua gudang genset dan wc umum penggunaannya sangat tidak optimal dikarena kerusakan bangunan tersebut. Oleh sebab itu, perlu dilakukan perbaikan atas fasilitas yang mengalami kerusakan agar seluruh fasilitas di komplek pergudangan BGR Indramayu digunakan secara optimal.

\section{PEMBAHASAN}

\section{1) Hasil Evaluasi Berdasarkan Indikator Fisik}

Indikator physical digunakan dalam mengukur keadaan fisik bangunan dalam hal kesesuaian (seberapa baik bangunan mendukung fungsi yang diinginkan), kualitas ruang (spasial, lingkungan, dan masalah psikologis), aksesibilitas (letak, lokasi, dan aksesibilitas penyandang cacat), dan konsumsi sumber daya (energi, air, dan material).

\section{a. Building physical condition - general building maintenance}

Sebagai upaya pemeliharaan preventif, BGR Logistics memberlakukan aturan untuk dilaksanakannya kegiatan "Jumat Bersih". Kegiatan ini mengharuskan seluruh karyawan yang bekerja di gudang untuk melakukan kegiatan bersih-bersih pada seluruh kawasan di komplek pergudangan setiap hari jumat. Gambar 4.1 menunjukan dokumentasi kegiatan jumat bersih yang dilakukan oleh karyawan di komplek pergudangan BGR Indramayu. 
Selain pada hari jumat, pemeliharaan kebersihan pun rutin dilakukan setiap hari kerja, namun dengan porsi yang lebih ringan. Pemeliharaan kebersihan rutin yang dilakukan setiap hari meliputi kegiatan sapu lantai kantor administrasi, gudang penyimpanan, pos jaga dan halaman.

Pemeliharaan kawasan secara korektif dilakukan dengan cara perbaikan ringan hingga perbaikan besar pada beberapa komponen bangunan. Perbaikan ringan meliputi perbaikan pada atap yang bocor, perbaikan plafon yang rusak, dan perbaikan komponen toilet jika mengalami kerusakan. Sedangkan perbaikan berat yang telah dilaksanakan berupa perbaikan pada emplasemen, loading dock, lantai, dinding, talang, kanopi, elektrikal, dan pagar hingga mencapai biaya sebesar Rp. 329.280.000,00. Namun setelah di lakukan observasi lapangan, kerusakan tetap terjadi pada komponen dari masing-masing fasilitas bangunan. Pada gudang penyimpanan beberapa bagian pada pintu gudang berkarat, beberapa titik pada pipa air bocor, lantai gudang retak, konstruksi baja pada bangunan sudah berkarat, dan toilet dalam gudang tidak terawat. Sedangkan di kantor administrasi lantai halaman rusak, kondisi dapur tidak tertata dan terdapat keretakan pada mejanya.

Disamping itu, terdapat pula fasilitas yang terbengkalai dan sama sekali tidak digunakan karena kondisinya yang rusak berat. Fasilitas tersebut adalah dua buah ruang genset dan wc umum. Tabel 2. menunjukkan kondisi pada ketiga fasilitas tersebut.

Tabel 2. Kondisi eksisting fasilitas gudang genset dan wc umum

\begin{tabular}{lll}
\hline \multicolumn{1}{c}{ Fasilitas } & \multicolumn{2}{c}{ Keterangan } \\
\hline Gudang Genset 1 & 1) Konstruksi bangunan rapuh \\
& 2) Komponen-komponen bangunan rusak \\
& seperti dinding, pintu, dan jendela \\
& 3) Generator tidak berfungsi \\
& 4) Sistem pencahayaan dan listrik sudah tidak \\
& berfungsi \\
\hline Gudang Genset 2 & 1) Atap bocor, dinding tidak terawat dan \\
& generatornya rusak \\
\hline 2) Generator tidak berfungsi \\
\\
3) Pencahayaan dan listrik sudah tidak berfungsi \\
\hline 1) Sebagian atap rusak \\
2) Daun pintu terlepas dari engselnya \\
3) Saluran sanitasi sudah tidak berfungsi \\
4) Sistem pencahayaan dan listrik sudah tidak \\
\end{tabular}


Indikator ini membahas mengenai kondisi fisik bangunan secara kualitatif termasuk pemeliharaan dalam hal perawatan rutin, perbaikan ringan dan berat. Menurut Akmal (2013), salah satu penyebab utama kerusakan bangunan adalah faktor umur bangunan. Seiring bertambahnya usia kualitas daya tahan material pembentuk bangunan dapat menurun. Hal ini menunjukan bahwa kerusakan komponen yang terjadi pada bangunanbangunan yang ada di komplek pergudangan BGR Indramayu diakibatkan oleh faktor umur bangunan. Mengingat komplek pergudangan BGR Indramayu telah berdiri selama 44 tahun, yang berarti sudah melewati umur ekonomisnya yaitu 30 tahun. Pemeliharaan preventif sudah tidak efektif diterapkan untuk meningkatkan kinerja fasilitas bangunanbangunan di komplek pergudangan BGR Indramayu. Perlu dilakukan peremajaan kawasan dengan cara rejuvenasi untuk mengembalikan kinerja bangunan agar dapat digunakan secara optimal.

\section{b. Waste}

Limbah yang dihasilkan dari kegiatan operasional di komplek pergudangan BGR Indramayu terdiri dari sampah rumah tangga atau domestik. Karena sampah yang dihasilkan sedikit, maka sampah dikelola dengan cara konfensional yaitu dengan dibakar diruang terbuka yang terletak di pinggir kantor administrasi. Kegiatan pembakaran sampah dilarang dilakukan menurut Undang-Undang Republik Indonesia Nomor 18 Tahun 2008 tentang Pengelolaan Sampah. Sampah rumah tangga dan sampah sejenis sampah rumah tangga dapat ditangani dengan cara: (a) dipilah dalam bentuk pengelompokan dan pemisahan sampah sesuai dengan jenis, jumlah, dan/atau sifat sampah; (b) dikumpulkan dalam bentuk pengambilan dan pemindahan sampah dari sumber sampah ke tempat penampungan sementara atau tempat pengolahan sampah terpadu; (c) diangkut dalam bentuk membawa sampah dari sumber dan/atau dari tempat penampungan sampah sementara atau dari tempat pengolahan sampah terpadu menuju ke tempat pemrosesan akhir; (d) diolah dalam bentuk mengubah karakteristik, komposisi, dan jumlah sampah; dan/atau (e) pemrosesan akhir sampah dalam bentuk pengembalian sampah dan/atau residu hasil pengolahan sebelumnya ke media lingkungan secara aman. Oleh karena itu, penanganan sampah di komplek pergudangan BGR Indramayu perlu mengikuti salah satu poin yang telah dipaparkan.

\section{c. Health and safety}


Berdasarkan hasil wawancara, tidak pernah terjadi kecelakaan saat melaksanakan kegiatan operasional di komplek pergudangan BGR Indramayu. Hal ini didukung oleh fasilitas penunjang kesehatan dan keselamatan kerja (K3) yang tersedia terdiri dari: alat pelindung diri (APD) yang terdiri dari rompi safety vest, helm pengaman, dan sepatu boot, 4 buah APAR 3,5 kg (disimpan di gudang penyimpanan), serta kotak P3K dan APAR 3,5 $\mathrm{kg}$ (disimpan di kantor administrasi). Standar peralatan K3 yang harus ada pada aktivitas pergudangan yaitu Alat Pelindung Diri (APD), kotak P3K, dan Alat Pemadam Api Ringan (APAR). Tujuan utama penyelenggaraan K3 adalah untuk mencegah, mengurangi, dan berusaha mengurangi risiko kecelakaan kerja (zero accident). Dalam hal ini, penerapan K3 di komplek pergudangan BGR Indramayu telah sesuai dengan standar yang ada dan dapat dikatakan baik karena risiko kecelakaan yang terjadi sangat minim (zero accident).

\section{d. Indoor Environmental Quality (IEQ)}

Berdasarkan hasil observasi dan wawancara, tidak terdapat termometer untuk mengukur suhu udara di dalam gudang, juga tidak terdapat higrometer untuk mengukur kelembaban di dalam area gudang. Pencahayaan di dalam gudang pada siang hari ditunjang dari pencahayaan pada sebagian atap yang menggunakan bahan transparan dan juga melalui ventilasi udara. Berdasarkan Peraturan Kepala Badan Pengawas Perdagangan Berjangka Komoditi No. 3 Tahun 2007 tentang Persyaratan Umum Dan Persyaratan Teknis Gudang Tertutup Dalam Sistem Resi Gudang, gudang harus mempunyai peralatan higrometer dan termometer untuk mengukur kelembaban dan suhu udara dalam gudang. Peraturan tersebut pun mengatur mengenai ventilasi yang harus ditutup dengan jaring kawat penghalang untuk menghindari gangguan burung, tikus dan gangguan lainnya. Dalam hal ini, kondisi eksisting pada gudang penyimpanan di komplek pergudangan BGR Indramayu tidak sesuai dengan peraturan yang berlaku. Sehingga, perlu dilakukan pengadaan peralatan-peralatan tersebut.

\section{e. Accesibility for disable}

Berdasarkan hasil observasi dilapangan, tidak ditemukan fasilitas penunjang yang berfungsi untuk mengakomodasi kebutuhan para penyandang cacat di komplek pergudangan BGR Indramayu. Fasilitas toilet di kantor administrasi komplek pergudangan BGR Indramayu belum menyediakan toilet yang dapat digunakan oleh penyandang disabilitas. Setiap fasilitas perlu memerhatikan ketentuan untuk penyandang cacat dan kesiapan fasilitas untuk mengakomodasi kebutuhan khusus para penyandang cacat. Hal ini diukur atas dasar tingkat aksesibilitas fasilitas bagi individu penyandang cacat. Peraturan 
Menteri Pekerjaan Umum nomor 32 tahun 2006 tentang Pedoman Teknis Fasilitas dan Aksesibilitas pada Bangunan Gedung dan Lingkungan pasal 3 ayat (1) menyatakan bahwa "Dalam merencanakan dan melaksanakan pembangunan bangunan gedung dan lingkungan, harus dilengkapi dengan penyediaan fasilitas dan aksesibilitas". Aksesibilitas disini berarti kemudahan yang disediakan bagi semua orang termasuk penyandang cacat dan lansia guna mewujudkan kesamaan kesempatan dalam segala aspek kehidupan dan penghidupan. Oleh karenanya, di komplek pergudangan BGR Indramayu pun seharusnya sudah menerapkan lingkungan yang ramah terhadap penyandang cacat. Standar fasilitas dan aksesibilitas untuk penyandang cacat yaitu toilet duduk yang dilengkapi dengan pegangan rambat, peletakan rambu sesuai jarak dan sudut pandang, dan jalur disabilitas.

\section{f. Security}

Sebagai upaya pengamanan di komplek pergudangan BGR Indramayu telah disediakan pos jaga, yang berfungsi untuk mengawasi setiap aktivitas yang terjadi di kawasan tersebut. Pos jaga tersebut dihuni oleh seorang penjaga yang bertugas hanya pada malam hingga pagi hari. Terdapat CCTV yang di pasang di area komplek pergudangan sebagai sistem keamanan. Namun, belum seluruh pembatas area komplek pergudangan BGR Indramayu diberi pagar, hanya bagian depannya saja yang sudah diberikan pengaman pagar pembatas. Pada bagian belakang yang tidak diberi pagar, pembatas hanya berupa tiang penanda pada setiap sudutnya.

Indikator security menggambarkan kondisi keamanan dan efektivitas langkah-langkah keamanan di fasilitas atau organisasi. Berdasarkan Peraturan Kepala Badan Pengawas Perdagangan Berjangka Komoditi No. 3 Tahun 2007 tentang Persyaratan Umum dan Persyaratan Teknis Gudang Tertutup Dalam Sistem Resi Gudang, area pergudangan harus memiliki sistem keamanan, ruang jaga dan pagar kokoh disekelilingnya. Komplek pergudangan BGR Indramayu telah memiliki sistem keamanan dibantu dengan perangkat CCTV dan juga ruang jaga. Namun belum terdapat pagar kokoh disekelilingnya, sehingga perlu dilakukan pengadaan pagar pembatas kawasan pergudangan.

\section{g. Site and Location}

Komplek pergudangan BGR Indramayu berdiri diatas lahan seluas $10.000 \mathrm{~m}^{2}$ yang ditunjang dengan beberapa fasilitas didalamnya. Lokasi komplek pergudangan BGR Indramayu berada pada kawasan pertanian yang bebas banjir dan longsor. Penentuan lokasi ini sesuai dengan gagasan didirikannya BGR yaitu berdasarkan adanya kebutuhan badan usaha yang dapat mengelola fasilitas pendukung sarana distribusi pupuk yang memadai 
berupa fasilitas gudang yang lokasinya menjangkau ke sentra-sentra pertanian. Terletak dipinggir jalan arteri yang dapat dilalui oleh kendaraan roda dua hingga truk pengangkut barang, juga dilalui oleh angkutan umum bus. Komplek Pergudangan BGR Indramayu berjarak 7,9 KM ke arah selatan dari jalan Raya Pantura.

Berdasarkan Peraturan Kepala Badan Pengawas Perdagangan Berjangka Komoditi No. 3 Tahun 2007 tentang Persyaratan Umum dan Persyaratan Teknis Gudang Tertutup Dalam Sistem Resi Gudang, lokasi gudang harus berada di dekat atau di pinggir jalan kelas I/II/perairan untuk memudahkan keluar dan masuk area gudang sehingga menjamin kelancaran kegiatan bongkar muat dan distribusi, berada di daerah yang aman dari banjir dan longsor, jauh dari pabrik atau gudang bahan kimia berbahaya, Stasiun Pengisian Bahan Bakar Umum dan/atau tempat pembuangan sampah/limbah kimia, terpisah dengan bangunan lain di sekitarnya sehingga keamanan dan keselamatan barang yang disimpan lebih terjamin dan tidak mengganggu keselamatan penduduk di sekitarnya, serta tidak terletak pada tempat bekas pembuangan sampah dan bekas pabrik bahan kimia. Dari seluruh persyaratan diatas, komplek pergudangan BGR Indramayu telah memenuhi persyaratan lokasi sesuai dengan peraturan yang berlaku.

\section{2) Hasil Evaluasi Berdasarkan Indikator Fungsional}

Indikator fungsional digunakan dalam mengukur kinerja fungsi bangunan atau fasilitas dengan mengevaluasi aspek yang berkaitan dengan misi organisasi atau bisnis, ruang, karyawan, dan fasilitas pendukung lainnya. Terdapat tiga indikator yang berkaitan dengan pengukuran kinerja fasilitas komplek pergudangan yaitu:

\section{a. Parking}

Sebagai salah satu fasilitas penunjang dalam kegiatan pergudangan, ruang parkir menjadi salah satu syarat kelengkapan dari sebuah kawasan pergudangan. Telah tersedia area parkir di komplek pergudangan BGR Indramayu, namun tidak ada petunjuk secara jelas yang menerangkan daerah mana saja yang merupakan tempat parkir. motor dan mobil yang diparkirkan dimana saja tanpa adanya area parkir khusus. Sedangkan untuk truk, dapat parkir disekitar gudang tanpa adanya rambu yang jelas. Menurut hasil wawancara, komplek pergudangan BGR Indramayu dapat menampung maksimal 9 buah kendaraan truk dalam satu waktu.

Peraturan Kepala Badan Pengawas Perdagangan Berjangka Komoditi No. 3 Tahun 2007 tentang Persyaratan Umum dan Persyaratan Teknis Gudang Tertutup Dalam Sistem Resi Gudang menyatakan bahwa gudang harus mempunyai fasilitas area parkir dengan luas 
yang memadai. Untuk klasifikasi gudang tertutup golongan B, minimal luas area parkir yang tersedia adalah $350 \mathrm{~m}^{2}$.

Area parkir yang tersedia di komplek pergudangan BGR Indramayu melebihi ukuran luas yang ditetapkan dalam peraturan. Namun, karena tidak ada rambu yang jelas dan area parkir yang terpisah berdasarkan jenis kendaraannya, luasan area parkir pun jadi tidak jelas. Oleh karena itu, perlu dilakukannya pengadaan rambu dan perbaikan area parkir di komplek pergudangan BGR Indramayu.

\section{b. Space utilization}

Berdasarkan hasil observasi dan wawancara, di komplek pergudangan BGR Indramayu beberapa fasilitas yang tersedia yaitu gudang penyimpanan, kantor administrasi, dan pos jaga telah beroperasi secara optimal karena digunakan sesuai dengan jam kerja yang berlaku. Namun, terdapat beberapa aset yang belum bekerja optimal karena sudah tidak berfungsi yaitu gudang genset dan toilet umum. Tabel 3 menunjukan persentase penggunaan ruang per hari di komplek pergudangan BGR Indramayu.

Tabel 3. Persentase Penggunaan Ruang Tahun 2019

\begin{tabular}{|c|c|c|c|c|c|c|c|}
\hline \multirow[t]{2}{*}{ No } & \multirow[t]{2}{*}{ Bangunan } & \multicolumn{2}{|c|}{ Target Penggunaan } & \multicolumn{2}{|c|}{ Eksisting } & \multicolumn{2}{|c|}{ Idle } \\
\hline & & Hari & $\%$ & Hari & $\%$ & Hari & $\%$ \\
\hline \multirow[t]{2}{*}{1} & Gudang Penyimpanan & 296 & $100 \%$ & 294 & 99,32 & 2 & 0,6 \\
\hline & & & & & $\%$ & & $8 \%$ \\
\hline \multirow[t]{2}{*}{2} & Kantor Administrasi & 296 & $100 \%$ & 294 & 99,32 & 2 & 0,6 \\
\hline & & & & & $\%$ & & $8 \%$ \\
\hline \multirow[t]{2}{*}{3} & Pos Jaga & 296 & $100 \%$ & 296 & 100 & 0 & $0 \%$ \\
\hline & & & & & $\%$ & & \\
\hline \multirow[t]{2}{*}{4} & Ruang Genset 1 & 296 & $100 \%$ & 0 & $0 \%$ & 296 & 100 \\
\hline & & & & & & & $\%$ \\
\hline \multirow[t]{2}{*}{5} & Ruang Genset 2 & 296 & $100 \%$ & 0 & $0 \%$ & 296 & 100 \\
\hline & & & & & & & $\%$ \\
\hline 6 & WC Umum & 296 & $100 \%$ & 0 & $0 \%$ & 296 & 100 \\
\hline
\end{tabular}

Target penggunaan dihitung berdasarkan jumlah hari kerja selama setahun dikurangi hari libur nasional. Jadwal operasional di komplek pergudangan BGR Indramayu dimulai dari hari senin hingga sabtu, setelah dikurangi hari libur nasional maka didapatkan total jam kerja pertahunnya adalah 296 hari.

Gudang penyimpanan dan kantor administrasi beroperasi sesuai jam kerja karyawannya. Pada tahun 2019, terdapat dua hari dimana setiap karyawan wajib mengikuti kegiatan kantor cabang yaitu pada tanggal 11 April 2019 saat diadakan acara hut BGR ke 42 dan pada tanggal 28 September 2019 saat diadakan pelatihan pergudangan. Sehingga total 
penggunaan gudang penyimpanan dan kantor administrasi per tahunnya adalah 294 hari. Sehingga persentase penggunaan kedua ruang tersebut sebesar 99,32\% dari target yang telah ditetapkan. Sedangkan untuk pos jaga karena petugasnya bukan merupakan karyawan tetap BGR maka ketika diadakan kegiatan kantor cabang tidak diikut sertakan. Oleh karena itu, persentase penggunaan pos jaga pertahunnya sesuai dengan target yang ingin dicapai. Kedua ruang genset dan wc umum sudah tidak difungsikan sama sekali, sehingga presentase penggunaan ruang pada ketiga fasilitas tersebut adalah $0 \%$.

Berdasarkan perhitungan diatas, dapat diketahui bahwa fasilitas gudang penyimpanan, kantor administrasi, dan pos jaga digunakan secara optimal. Sedangkan kedua gudang genset dan wc umum penggunaannya sangat tidak optimal dikarena kerusakan bangunan tersebut. Oleh sebab itu, perlu dilakukan perbaikan atas fasilitas yang mengalami kerusakan agar seluruh fasilitas di komplek pergudangan BGR Indramayu digunakan secara optimal.

\section{c. Adequancy of space}

Fasilitas yang terdapat di komplek pergudangan BGR Indramayu terdiri dari gudang penyimpanan, kantor administrasi, pos jaga, gudang genset, wc umum dan area parkir. Berdasarkan Peraturan Menteri Perdagangan Republik Indonesia No. 90 Tahun 2014 tentang Penataan dan Pembinaan Gudang, gudang penyimpanan di komplek pergudangan BGR Indramayu termasuk kedalam gudang tertutup golongan B, karena memiliki luas $1.440 \mathrm{~m}^{2}$ dengan kapasitas penyimpanan sebesar $3.500 \mathrm{~m}^{3}$. Maka menurut Peraturan Kepala Badan Pengawas Perdagangan Berjangka Komoditi No. 3 Tahun 2007 tentang Persyaratan Umum dan Persyaratan Teknis Gudang Tertutup Dalam Sistem Resi Gudang, gudang tertutup golongan B harus memiliki fasilitas ruang administrasi di luar gudang, wc di luar gudang, ruang jaga di luar gudang, dan area parkir luas minimal $350 \mathrm{~m}^{2}$.

Semua fasilitas tersebut telah tersedia di komplek pergudangan BGR Indramayu. Kegiatan operasional pergudangan disana ditunjang dengan adanya fasilitas-fasilitas tersebut. Masing-masing ruang memiliki fungsinya tersendiri. Gudang penyimpanan berfungsi dengan baik sebagai tempat distribusi pupuk dengan kapasitas $3500 \mathrm{~m}^{3}$. Kantor administrasi berfungsi dengan baik sebagai tempat diolahnya data administratif pergudangan, luasnya yang sebesar $54 \mathrm{~m}^{2}$ cukup untuk dihuni dua orang karyawan yaitu kepala gudang dan staf administrasi gudang. Ruang pos jaga memiliki luas bangunan sebesar $15 \mathrm{~m}^{2}$ cukup untuk dihuni seorang penjaga keamanan. WC umum memiliki luas 3 
$\mathrm{m}^{2}$, dengan jumlah wc sebanyak 4 slot cukup untuk digunakan oleh pekerja lepas di gudang BGR, namun fasilitas tersebut sudah tidak berfungsi. Maka dapat disimpulkan bahwa kecukupan ruang di komplek pergudangan BGR Indramayu sudah memadai, namun masih memerlukan beberapa perbaikan untuk meningkatkan kinerja fasilitas-fasilitas tersebut.

\section{KESIMPULAN DAN SARAN}

\section{Kesimpulan}

Berdasarkan hasil evaluasi kinerja fasilitas aset komplek pergudangan BGR Indramayu, maka dapat ditarik kesimpulan bahwa:

1. Berdasarkan dimensi physical, komplek pergudangan BGR Indramayu memiliki kinerja bangunan yang belum optimal. Pemeliharaan preventif sudah tidak efektif diterapkan pada fasilitas tersebut karena umur bangunan yang sudah tua. Kegiatan pengelolaan sampah di komplek pergudangan BGR Indramayu masih menggunakan cara konfensional yaitu dengan cara dibakar. Peralatan kesehatan dan keselamatan kerja (K3) sudah sesuai dan memadai. Namun, komplek pergudangan BGR Indramayu belum memiliki beberapa aspek seperti: fasilitas yang memadai untuk para penyandang cacat, pagar kokoh di sekeliling komplek pergudangan. Sedangkan untuk lokasi gudang sudah memenuhi peraturan yang berlaku. Sehingga, sebaiknya dilakukan peremajaan kawasan dengan cara rejuvenasi untuk mengembalikan kondisi bangunan yang sudah tua agar kembali prima. Ditunjang dengan fasilitas yang memadai berupa: tempat sampah yang sesuai dengan jenis, jumlah, dan/atau sifat sampah, penyediaan peralatan penunjang gudang seperti thermometer, higrometer, dan perbaikan sistem ventilasi gudang, disediakan fasilitas pendukung untuk penyandang cacat, melengkapi dengan bagar pembatas disekeliling area gudang

2. Berdasarkan dimensi functional, komplek pergudangan BGR Indramayu memiliki kinerja fasilitas yang belum optimal. Komplek pergudangan tersebut berfungsi dengan baik dilihat dari segi kecukupan ruang yang dibutuhkan dalam operasionalnya. Namun, masih terdapat permasalahan dari segi fungsionalnya yaitu tidak adanya penanda di area parkir yang mengakibatkan kendaraan parkir disembarang tempat dan terdapat beberapa fasilitas rusak yang tidak mendapat perbaikan sehingga terbengkai. Oleh karena itu, sebaiknya dilakukannya pengadaan rambu dan perbaikan area parkir dan perbaikan atas 
fasilitas yang mengalami kerusakan berat (gudang genset dan wc umum) agar seluruh fasilitas di komplek pergudangan BGR Indramayu dapat digunakan secara optimal.

\section{Saran}

Berdasarkan kesimpulan yang telah dipaparkan, maka saran yang diajukan pada penelitian studi kasus ini adalah:

1. Pada dimensi physical, sebaiknya dilakukan peremajaan kawasan dengan cara rejuvenasi untuk mengembalikan kondisi bangunan yang sudah tua agar kembali prima. Ditunjang dengan fasilitas yang memadai berupa: tempat sampah yang sesuai dengan jenis, jumlah, dan/atau sifat sampah, penyediaan peralatan penunjang gudang seperti thermometer, higrometer, dan perbaikan sistem ventilasi gudang, disediakan fasilitas pendukung untuk penyandang cacat, melengkapi dengan bagar pembatas disekeliling area gudang.

2. Pada dimensi functional, sebaiknya dilakukannya pengadaan rambu dan perbaikan area parkir dan perbaikan atas fasilitas yang mengalami kerusakan berat (gudang genset dan wc umum) agar seluruh fasilitas di komplek pergudangan BGR Indramayu dapat digunakan secara optimal.

\section{DAFTAR PUSTAKA}

Campbell, John D., Jardine, Andrew K. S, \& McGlynn, Joel. 2011. Asset Management Excellence. United State of America: CRC Press Taylor and Francis Group.

Lavy, S., Garcia, J. A., \& Dixit, M. K, (2010). Establishment of KPIs for facility performance measurement: review of literature. Facilities, Vol. 28 Iss 9/10 pp. $440-$ 464.

Mangano, G., \& Marco, A. D. (2014). The role of maintenance and facility management in logistics: a literature review. Facilities, Vol. 32 Iss 5/6 pp. $241-255$.

Siregar, Doli. 2004. Manajemen Aset : Strategi Penataan Konsep Pembangunan Berkelanjutan secara Nasional dalam Konteks Kepala Daerah sebagai CEO's pada Era Globalisasi \& Otonom Daerah. Jakarta: Gramedia Pustaka Utama.

Sugiama, A Gima. 2013. Manajemen Aset Pariwisata. Bandung: Guardaya Intimarta.

Hastings, Nicholas A. John. 2010. Physical Asset Management. Springer.

Sugiama, A Gima. (2008). Metode Riset Bisnis dan Manajemen (Edisi Pertama). Bandung: Guardaya Intimarta.

Duffuaa, Salih O., dan Raouf, A. 2015. Planning and Control of Maintenance System Modeling and Analysis second edition. Switerzerland : Springer

Mobley, R. Keith. 2004. Maintenance fundamentals $\left(2^{\text {nd }}\right.$ ed). United Kingdom: Elsivier Butterworth-Heineman.

Barry, Render dan Jay Heizer. 2001. Prinsip-prinsip Manajemen Operasi: Operations Management. Jakarta: Salemba Empat 
Daryus, Asyari. (2007). Diktat Manajemen Pemeliharaan Mesin. Jakarta: Universitas Darma Persada.

Mapfre, R.E. 2008. Warehouse safety guide. Spanyol. http://mapfrere.com

Rusthon, Alan dkk. 2010. The Handbook of Logistics \& Distribution Management. New Delhi: Replika Press.

Purnomo, Hari. 2004. Perencanaan dan Perancangan Fasilitas, Edisi Pertama, Yogyakarta: Graha Ilmu.

Apple. M.J. 1990. Tata letak Pabrik Dan Pemindahan Bahan. ITB Bandung.

Bowersox, D.J. 1978. Manajemen Logistik: Integrasi Sistem-Sistem Manajemen Distribusi Fisik dan Manajemen Material (terjemahan Drs. A. Hasymi Ali). Jakarta: Penerbit Bumi Aksara.

Stock, J.R. \& Lambert, D.M. 2001. Strategic Logistics Management. Edisi Keempat. Singapore: McGraw-Hill.

Parlementer, D. 2014. Key Performance Indicators-developing, Implementing, and Using Winning KPIs. Jakarta: PPM Manajemen.

Peraturan Menteri Perdagangan Republik Indonesia No. 90 Tahun 2014 tentang Penataan dan Pembinaan Gudang.

Peraturan Kepala Badan Pengawas Perdagangan Berjangka Komoditi No. 3 Tahun 2007 tentang Persyaratan Umum Dan Persyaratan Teknis Gudang Tertutup Dalam Sistem Resi Gudang.

Peraturan Menteri Pekerjaan Umum No. 30 Tahun 2006 tentang Pedoman Teknis Fasilitas dan Aksesibilitas Pada Bangunan Gedung dan Lingkungan.

Peraturan Menteri Pekerjaan Umum nomor 32 tahun 2006 tentang Pedoman Teknis Fasilitas dan Aksesibilitas pada Bangunan Gedung dan Lingkungan.

Undang-Undang Republik Indonesia Nomor 18 Tahun 2008 tentang Pengelolaan Sampah. 